DOI https://doi.org/10.36059/978-966-397-235-0-13

\author{
Марущак А. В., \\ orcid.org/0000-0002-4611-4906 \\ кандидат юридичних наук, доцент, \\ доцент кафедри конституційного, адміністративного та \\ фінансового права \\ Чернівецького юридичного інституту \\ Національного університету «Одеська юридична академія», \\ м. Чернівці
}

\title{
ПРАВА ЛЮДИНИ В ЕПОХУ ДІДЖИТАЛІЗАЦІї
}

\begin{abstract}
Анотація. Наукове дослідження присвячене аналізу впливу діджиталізації на реалізацію прав людини $і$ громадянина. Охарактеризовані наслідки, спричинені використанням інформаційно-комунікаційних технологій у сфері здійснення прав людини. Проаналізовано покоління прав людини, включаючи новітне четверте покоління. Обгрунтовано зростаючу роль інноваційних технологій $і$ їх вплив на новації у міжнародному та вітчизняному законодавствах. Відзначено, що жоден із вітчизняних політичних, соціальних чи правових інститутів не наздогнав наслідків переходу розвитку краӥни до епохи діджиталізації. Досліджено процес цифровізації прав людини та громадянина. Запропоновано розглядати цифрові права як форму здійснення основних прав людини, де з позиції діалектики основні права людини та цифрові права співвідносяться між собою як зміст і форма.

Проаналізовано основні та найбільш актуальні електронні способи здійснення деяких прав громадян. Вказано, що однією $з$ основних проблем низького рівня участі громадян у електронній демократії й електронному урядуванні є соціально-демографічні характеристики. Запропоноване вирішення цієї проблеми за допомогою впровадження цифрової (електронної) інклюзї̈.
\end{abstract}

\section{Вступ}

Епоха діджиталізації становить певні часові рамки в історії, коли використання цифрових технологій стало поширеним i загальновживаним у всьому світі. Ї̈̈ початком можна вважати 
період, коли суспільство опанувало Інтернет, коли були введені персональні комп'ютери та інші технології, щоб забезпечити користувачам можливість легкої та швидкої передачі інформації.

Використання інформаційних даних стало досить розповсюдженою водночас майже непомітною частиною нашого повсякденного життя. Кожна наша взаємодія 3 технологіями, починаючи від використання банківської картки в магазині, на онлайн-ресурсах і закінчуючи вподобанням допису на Facebook, долучає людей до майже необмеженого сховища інформації, створеного ними та про них.

Наше сьогодення - це розквіт інформаційної епохи. Історичний період XXI ст. характеризується швидким переходом від традиційної промисловості, оскільки промислова революція призвела до індустріалізації та становлення економіки, заснованої на інформаційних технологіях, але водночас жоден із політичних, соціальних чи правових інститутів не наздогнав наслідків цього переходу, відбувається переосмислення засобів і методів захисту прав людини, адже правозахисний рух повинен наздогнати цифрову реальність.

Епоха діджиталізації відрізняється певною залежністю від інформаційно-комунікаційних технологій. Так, нині соціальна, політична й економічна діяльність у більшості держав так чи інакше пов'язана з використанням цифрових технологій, про що свідчить багато випадків сучасних нововведень у різних сферах. До прикладу, електронний банкінг, який вже давно зайняв одну 3 лідируючих позицій у сфері банківських послуг по всьому світу і протягом останніх років характеризується стрімким розвитком, зокрема і в Україні [1].

Інформаційна епоха, комп'ютерна епоха - це все частини концепції, котра охоплює повсюдний характер обчислювальної техніки та плідне використання технологій майже у всіх аспектах людської діяльності таким чином, що цифрова взаємодія стає визначальною характеристикою людської діяльності

Разом із новими можливостями досягнутий рівень цифрових технологій одночасно чинить і певні перешкоди у реалізації принципу верховенства права.

\section{1. Права людини нового покоління}

Поширеність інформаційних і комунікаційних технологій у сучасному світі робить практично неможливим ведення 
повсякденного життя без цих технологій. Люди використовують Інтернет, щоб задовольнити найрізноманітніші людські потреби, такі як робота, покупки, безпека, спілкування, розваги та інші особисті цілі. Інтернет-простір часто забезпечує задоволення різних інтересів населення, і тим не менш усі його дії, дані пошукових запитів, обмін інформацією записується у цифрову вічність. Серед найбільш обговорюваних ризиків внаслідок реалізації прав людини можна виділити порушення у сфері безпеки, конфіденційності та репутації.

3 одного боку, діджиталізація пропонує інноваційні вирішення для деяких проблем верховенства права, як, наприклад: підвищення рівня відповідальності уряду шляхом розширення доступу до інформації; сприяння встановленню прозорості, оскільки громадяни можуть збирати та розповсюджувати докази порушень прав людини; розширення спектру можливостей доступу до ефективних засобів правового захисту. 3 іншого боку, діджиталізація провокує і негативні наслідки: недостатній рівень гарантій конфіденційності; ризик підвищення кількості кіберзлочинів; нездатність законодавства повною мірою захистити громадян від неправомірних маніпуляцій у сфері цифрових технологій.

Негативні наслідки вказують на нагальну потребу у забезпеченні верховенства права у відносинах із використанням цифрових технологій. Це своєрідний виклик для законодавця, який спонукає до оновлення нормативно-правової бази, що регулює ці суспільні відносини.

Інтернет став незамінним інструментом для реалізації низки прав людини. Цифрові технології неминуче чинять свій вплив і на права людини як у позитивному, такі і негативному аспектах. Вони трансформували засоби, за допомогою яких права людини здійснюються, зробили процес реалізації багатьох прав людини більш доступним, швидким, але водночас і стимулювали ріст випадків порушень останніх.

Враховуючи стрімкий розвиток науково-технічного прогресу, його беззаперечний вплив на реалізацію прав і свобод людини та громадянина, у науково-правовій доктрині дедалі частіше з'являються пропозиції «доповнити» теорію поколінь прав людини новим, четвертим поколінням.

Загальновизнано, що та система поколінь прав людини, яку ми знаємо сьогодні, складається із трьох. Автором цієї концепції 
Права людини в Україні та у зарубіжних країнах: традиції та новації

став французький і чеський юрист Карел Вашак, запропонувавши саме таку класифікацію прав людини у 1979 р.

Відповідне покоління прав відображає рівень історичного розвитку кожної окремої держави та світової спільноти загалом.

Права першого покоління були закріплені у національних і міжнародному законодавствах у VII-VIII ст. Це переважно громадянські та політичні права. Їх умовно можна розділити на дві підкатегорії. Перша стосується норм особистої та цивільної безпеки, тобто заборони рабства, вчинення актів катувань чи негуманного поводження 3 людьми. Друга підкатегорія стосується свободи віросповідання, права на політичну участь тощо.

Права людини другого покоління - це соціальні, економічні та культурні права. Вони засновані на ідеях рівності та гарантованого доступу до основних соціальних та економічних благ, послуг i можливостей. Ці права стали особливо актуальними, коли люди та держави почали визнавати, що права - це не просто спосіб захисту від домінування держави. Прикладами прав другого покоління $є$ право на охорону здоров'я, на працю, на відпочинок тощо.

Права людини третього покоління переважно охоплюються ідеєю самовизначення. Здебільшого за змістом це права самостійно визначати своє майбутнє, і така категорія належить до колективних прав. Це такі права, як: право на мир, на безпечне довкілля. Як зазначав сам автор теорії трьох поколінь прав людини Карел Вашак: «Третє покоління прав людини стосується спільнот і суспільства. Ця категорія прав базується на почутті солідарності, яке $\epsilon$ важливим для реалізації найважливіших проблем міжнародної спільноти, таких як мир і навколишнє середовище» [2].

Думка щодо четвертого покоління прав людини з'явилася завдяки швидкому світовому технологічному розвитку та тим змінам, що відбуваються у способах і формах реалізації прав людини та громадянина. Існують також небезпідставні припущення, що ріст науково-технічного прогресу не лише допомагає реалізовувати права, а і водночас ставить їх під загрозу посягання та порушення.

Цифрова трансформація забезпечує нові способи здійснення прав і свобод об'єднань громадян, спільнот, але також і нові загрози для обмеження їхніх прав. В епоху цифровізації законодавство потрібно адаптувати для захисту основних прав 
людини та громадянина. Цифрові права, тісно пов'язані зі свободою вираження поглядів і конфіденційністю, - це ті, які дозволяють людям отримувати доступ, використовувати, створювати та публікувати інформацію за допомогою інформаційно-комунікаційних систем. Отже, реалізації цих прав і ïx захисту велика увага повинна приділятися у спеціальних нормативно-правових актах, котрі регулюють право на інформацію загалом.

Термін «цифрові права» ще не має свого законодавчого закріплення та єдиного розуміння серед науковців, але останнім часом у науковому просторі дедалі частіше з'являються пропозиції щодо визначення його змісту.

Деякі науковці визначають цифрові права як універсальні права людини, адаптовані до умов інформаційного суспільства, зокрема право на недоторканність приватного життя, право на обмін інформацією, право на вільне вираження думки в мережі, право доступу до електронної мережі [3].

Інші пропонують розглядати поняття «цифрові права»не як окрему групу прав людини, а як умовну категорію, що охоплює особливості реалізації та гарантії захисту фундаментальних прав людини в Інтернеті, зокрема свободи вираження поглядів і права на приватність онлайн [4]. Цифрові права іноді розглядаються у науковій доктрині як об'єкти цивільних прав [5].

Що ж належить до цифрових прав? Аналізуючи наукову літературу, можна дійти висновку, що до цифрових прав відносять: право на свободу й особисту безпеку в онлайнпросторі; приватність; свободу вираження поглядів в онлайнпросторі; право на мирні зібрання, асоціації та використання електронних інструментів демократії; право на цифрове самовизначення, або право відключатися від онлайну тощо.

Як видно із вищевказаного, змістове наповнення цифрових прав не має значних відмінностей від категорії «основні права людини», крім однієї - усі вони здійснюються у мережі Інтернет, або за допомогою її використання. Видається цілком логічним розуміння цифрових прав як форми здійснення основних прав людини. 3 позицій діалектики основні права людини та цифрові права співвідносяться між собою як зміст і форма.

Наслідки цифрової трансформації основних свобод громадянського простору особливо актуальні в контексті охорони здоров'я та надзвичайних ситуацій, включаючи 
пандемію. Тоді як фізичний простір для інститутів громадянського суспільства істотно зменшився у всьому світі, цифрова трансформація відкриває нові можливості в Інтернеті. Це об'єднує громадянський простір на глобальному рівні, підтримує масову мобілізацію соціальних рухів в автономному режимі та створює більш динамічні й інклюзивні громадянські простори, що відзначаються більшою активністю та залученістю.

Цифровізація демократії участі суттєво вплинула процес і способи реалізації прав людини та громадянина. Наслідком впровадження нових можливостей за допомогою інформаційнокомунікаційних систем стала еволюція прав людини та поява нового, четвертого покоління прав.

Цифрові технології трансформують спосіб здійснення, захист і порушення основних прав, таких як свобода вираження поглядів і доступ до інформації, а також ведуть до визнання нових прав. Тому законодавство повинно адаптуватися до нової ери розвитку цифрових прав, дозволяючи та регулюючи доступ до Інтернет-інформації безпечно та прозоро. Говорячи про цифрові права, насамперед потрібно згадувати про право на Інтернет, впроваджене міжнародними актами, але варто взяти до уваги, що імплементація цього права у національне законодавство не завжди видається можливою. Країни третього сектору не готові до цього ,тому стверджувати щодо його обов'язковості на нинішньому етапі розвитку більшості країн досить парадоксально, але констатувати трансформацію засобів і способів реалізації вже наявних прав можна.

Крім розглянутих у дослідженні цифрових прав, до четвертого покоління вчені ще включають права на геном людини, генетичні маніпуляції, життєдіяльність, людські ембріони, евтаназію та євгеніку. Діяльність, пов'язана з перерахованими явищами, може породити складні юридичні питання з етичного, морального та релігійного поглядів. Рада Європейського Союзу із цього приводу рекомендує державам-членам прийняття основоположних принципів, які охоплюватимуть взаємозв'язок між генною інженерією та правами людини, щоб на право на життя та гідність не можна було посягати, використовуючи генетичні характеристики людей.

Згідно з дослідженням четверте покоління прав людини не $\epsilon$ ненауковою та безпідставною ідеєю, і деякі професори та дослідники права, особливо протягом останніх років, 
наголошують на необхідності виокремлення нового покоління прав людини. Основною причиною формування цього занепокоєння серед дослідників права є необхідність збереження людської гідності у сучасну епоху. Вчені доходять висновку, що до вищезазначених прав належать права людини, які виникли внаслідок розвитку медицини, біології, техніки та змін у загальній моралі [6].

У рамках четвертого покоління прав людини можна виокремити принаймні дві такі групи: так звані соматичні права та права, пов'язані з розвитком цифрових технологій, у т. ч. Інтернету. Етимологічно поняття «соматичний» («соматичні») походить від грецького слова «sоma» - «тіло». Тобто йдеться про групу прав людини, які пов'язані з ії можливістю самостійно розпоряджатися своїм тілом [7].

Таким чином, четверте покоління прав людини можна розглядати як правовий комплекс. Рамки четвертого покоління прав людини ще не визначені чітко ні 3 погляду правових принципів, ні з погляду чіткого окреслення кола таких прав.

Аналіз і дослідження цієї проблематики дозволить своєчасно підготуватися та сформувати необхідні умови задля комфортного існування та діяльності інститутів громадянського суспільства, враховуючи динамічний розвиток сучасності, адже вивчення різних можливостей того, як може виглядати майбутнє та шляхів його розвитку допомагає передбачити відповідні наслідки та сформувати необхідну політику вже сьогодні.

Стрімкий науково-технічний прогрес і виникнення нових інформаційних технологій, глобальні перетворення у соціальній та економічній сферах життя суспільства і держави ставлять нові завдання не лише перед суспільством і державою, а і перед юридичною наукою. Вони спрямовані на створення нових правових механізмів і правових конструкцій, які могли би за умов світової «цифрової революції» забезпечити адекватне правове регулювання правовідносин із використанням цифрових технологій. Можна констатувати, що завдяки новим цифровим технологіям має бути сформоване зовсім нове середовище правового регулювання.

Так чи інакше, можна стверджувати, що людство перебуває на порозі нової революції у галузі прав людини. 
Права людини в Україні та у зарубіжних країнах: традиції та новації

\section{2. Нормативне становлення цифровізації суспільства на міжнародному та вітчизняному рівнях}

Щодо важливості існування та розвитку інформаційного суспільства на міжнародному рівні заговорили ще у 2003 р. на Всесвітньому саміті 3 питань інформаційного суспільства в Женеві, результатом проведення якого стало прийняття Декларації принципів, у якій учасники відобразили своє спільне бачення інформаційного суспільства. Проведення саміту було розподілене на два етапи: у 2003 р. у Женеві та у 2005 р. у Тунісі. У 2003 р. кількість учасників становила 11 000, котрі представляли 175 країн, а у 2005 р. - більше 19 000, що представляли 174 країни.

Світовий саміт із питань інформаційного суспільства був першим масштабним окремим кроком у міжнародному обговоренні інформаційно-комунікаційних технологій (IКТ). Він акумулював багато різноманітних ресурсів міжнародних організацій, державних органів країн, організацій громадянського суспільства та бізнес-сфери. Його результатом стала підготовка чотирьох основоположних документів, які відображають спільне прагнення до формування інформаційного суспільства. Це забезпечило основу для дебатів міжнародного рівня щодо фінансування інфраструктури й управління Інтернетом, але існує думка, що саміт отримав лише обмежену увагу громадськості та не зміг подолати розрив у між світом інформаційних технологій і міжнародним розвитком [8].

На першому етапі проведення саміту було прийнято План дій для реалізації спільного бачення та керівних принципів, визначених у Декларації принципів, із метою сприяння досягненню міжнародно-узгоджених цілей розвитку шляхом підтримки використання ІКТ та допомоги країнам у подоланні цифрового розриву.

Декларація принципів під назвою «Побудова інформаційного суспільства: глобальний виклик у новому тисячолітті» відобразила загальне бажання та прагнення урядів побудувати інформаційне суспільство, орієнтоване на людей, яке буде інклюзивним і спонукатиме розвиток. Інформаційне суспільство, де кожен міг би створювати, отримувати доступ, використовувати й обмінюватися інформацією та знаннями, дозволяючи людям і спільнотам реалізовувати весь свій потенціал. Метою таких принципів $\epsilon$ покращення якості життя, 
виходячи із цілей і принципів Статуту Організації Об'єднаних Націй, повної поваги та дотримання Загальної декларації прав людини.

Підгрунтям виникнення інформаційного простору, необхідності його визнання на міжнародному рівні та правового визначення стала ст. 19 основоположного документа про права людини - Загальної декларації прав людини 1948 р., яка встановлює: «Кожна людина має право на свободу переконань і на вільне їх виявлення; це право включає свободу безперешкодно дотримуватися своїх переконань i свободу шукати, одержувати і поширювати інформацію та ідеї будьякими засобами та незалежно від державних кордонів» [9].

Крім того, було проголошено, що міжнародне управління Інтернетом має бути багатостороннім, прозорим i демократичним. Було визнано декілька ключових засад:

- політична влада щодо питань державної політики, пов'язаної з Інтернетом, повинна бути суверенним правом держав;

- приватний сектор повинен продовжувати відігравати важливу роль у розвитку Інтернету;

- громадянське суспільство повинно продовжувати відігравати важливу роль, особливо на рівні громад;

- міжурядові організації повинні сприяти координації питань державної політики, пов'язаної з Інтернетом [10].

На саміті було акцентовано увагу на тому, що ІКТ надають величезні можливості для усіх членів суспільства і повинні враховувати перспективи гендерної рівності.

Учасники саміту відзначили також особливі потреби маргіналізованих і вразливих груп суспільства, людей похилого віку. Було визнано, що побудова інклюзивного інформаційного суспільства вимагає нових форм солідарності, партнерства та співпраці між урядами та іншими зацікавленими сторонами, тобто приватним сектором, громадянським суспільством і міжнародними організаціями. Розуміючи, що мета подолання цифрового розриву вимагатиме твердої прихильності всіх зацікавлених сторін, уряди закликали до цифрової солідарності, оскільки усі зацікавлені сторони повинні працювати разом для покращення зв'язку. Універсальний, повсюдний, справедливий доступ до інфраструктури та послуг ІКТ повинен бути основною метою. Політика повинна сприяти атмосфері стабільності, 
передбачуваності та добросовісної конкуренції, щоб залучити більше приватних інвестицій для розвитку інфраструктури ІКТ. Спільне використання та зміцнення глобальних знань може бути посилено шляхом усунення бар'єрів для інформації та полегшення отримання інформації у відкритому доступі, а також шляхом підвищення обізнаності про можливості, пропоновані різними моделями програмного забезпечення, включаючи власне, відкрите та вільне програмне забезпечення.

Декларація «Побудова інформаційного суспільства: глобальний виклик у новому тисячолітті» затвердила 11 ключових принципів:

1) роль органів державної влади та всіх зацікавлених сторін у просуванні ІКТ для розвитку;

2) необхідна основа для інклюзивного інформаційного суспільства - це інформаційно-комунікаційна інфраструктура;

3) доступ до інформації та знань;

4) підвищення компетентності;

5) формування безпеки при використанні IКТ;

6) сприятливе середовище;

7) застосування IКТ надає переваги в усіх аспектах життя;

8) культурна різноманітність та ідентичність, мовна різноманітність і локальний зміст;

9) засоби масової інформації;

10) етичні передумови інформаційного суспільства;

11) міжнародне та регіональне співробітництво [10].

Пізніше, у 2005 р. відбувся другий етап проведення саміту у Тунісі, де було підтверджено прихильне ставлення до Декларації принципів. Результатом проведення другого етапу стала розробка двох нових документів: «Туніських зобов'язань» (Tunis Commitment) i «Туніської програми» (Tunis Agenda). Обидва документи підкреслюють три основні напрями діяльності, що охоплюють:

- визначення фінансових механізмів, які будуть використані для подолання «цифрового розриву»;

- сприяння дискусіям щодо управління Інтернетом;

- імплементацію документів Всесвітнього саміту з питань інформаційного суспільства.

«Туніська програма» також містить визначення терміна «управління Інтернетом»: розробка та застосування державними органами, приватним сектором і громадянським суспільством у 
Права людини в Україні та у зарубіжних країнах: традиції та новації

відповідних їм сферах спільних принципів, норм, правил, процедур прийняття рішень і програм, котрі сприяють використанню Інтернету та його розвитку [11].

Варто зазначити, що така дефініція визначає межі впливу й обов'язки кожної групи зацікавлених сторін, підкреслює важливість співпраці у пошуку рішень щодо зростання впливу та розвитку Інтернету. Це своєрідна модель багатосторонньої участі.

Таким чином, період із 2003 по 2005 рр. можна вважати початком міжнародного визнання важливості та необхідності широкого впровадження Інтернету. Зокрема, його суттєвого впливу на процес державного управління кожної країни окремо, міжнародного значення загалом і на реалізацію прав і свобод індивідів, що віддзеркалюється і на здійсненні прав інститутами громадянського суспільства.

Наступним рішучим кроком у становленні інформаційного суспільства у світі стало прийняття Резолюції Ради ООН з прав людини «Заохочення, захист і здійснення прав людини в Інтернеті» (A / HRC / RES / 20/8 16 червня 2012 р.), де було встановлено: «Ті самі права, які людина має в офлайн середовищі, повинні також захищатися і онлайн, зокрема право на свободу вираження поглядів, яке здійснюється незалежно від державних кордонів і через будь-які обрані засоби масової інформації відповідно до ст. 19 Загальної декларації прав людини і Міжнародного пакту про громадянські та політичні права» [12].

Резолюцією визначено декілька ключових аспектів:

- глобальна природа Інтернету як рушійної сили прискорення прогресу до розвитку у різних формах;

- $\quad$ необхідність усіх держав сприяти доступу до Інтернету та здійснювати міжнародне співробітництво, спрямоване на розвиток засобів масової інформації та засобів зв'язку у всіх країнах;

- урахування норм Резолюції у здійсненні окремих процедур у рамках наявних мандатів.

Ряд країн, а саме - Китай, Росія і Саудівська Аравія, хотіли внести поправки в резолюцію, але вони були відхилені в ході голосування. Представники згаданих країн були не згодні 3 деякими положеннями резолюції. Так, Китай і Росія висловилися проти можливості одержувати та передавати інформацію будьякими засобами і незалежно від державних кордонів, однак їхні 
поправки не були прийняті як такі, що відволікають увагу від піднятої проблеми свободи слова в Інтернеті. Варто сказати, що блокування певних доменів періодично практикується в деяких країнах, таких як Китай або Іран. Тепер вона стане де-юре незаконною, але актуальним залишається два питання: підпорядкування національних законодавств міжнародному та проголошення єдиних загальних правил де-юре і застосування зовсім інших де-факто.

За допомогою цієї Резолюції $\mathrm{OOH}$ закликає країни переглянути свої процедури, практику та законодавчі акти, які стосуються перлюстрації листування, а також заходи, що застосовуються 3 метою перехоплення i збору особистої інформації, включаючи практику масового стеження, з метою захисту права на недоторканність приватного життя. Тобто право громадян на недоторканність приватного життя має охоронятися в онлайні за тими самими принципами, які діють і в оффлайн.

За останні два десятиліття досягнення в галузі ІКТ змінили способи доступу людей до інформації, яку впроваджують державні органи. Наприклад, значно підвищилася кількість онлайн-платформ, котрі дозволяють користувачам подавати запити на інформацію відповідно до законодавства про право на інформацію. Це є одним із багатьох прикладів таких змін.

Право на інформацію у національному законодавстві закріплене Основним Законом України та Законом України «Про інформацію». Конституція України у ч. 2 ст. 34 встановлює: кожен має право вільно збирати, зберігати, використовувати i поширювати інформацію усно, письмово або в інший спосіб - на свій вибір [13]. Ст. 3 Закону України «Про інформацію» встановлює основні напрями державної інформаційної політики, серед яких $\epsilon$ і створення умов для формування в Україні інформаційного суспільства. Іншими напрямами є:

- забезпечення доступу кожного до інформації;

- забезпечення рівних можливостей щодо створення, збирання, одержання, зберігання, використання, поширення, охорони, захисту інформації;

- забезпечення відкритості та прозорості діяльності суб'єктів владних повноважень;

- створення інформаційних систем і мереж інформації, розвиток електронного урядування; 
Права людини в Україні та у зарубіжних країнах: традиції та новації

- постійне оновлення, збагачення та зберігання національних інформаційних ресурсів;

- забезпечення інформаційної безпеки України;

- сприяння міжнародній співпраці в інформаційній сфері та входженню України до світового інформаційного простору [14].

Тобто про цифровізацію суспільства на державному рівні заговорили ще у 1992 р.

Важливим кроком до створення інформаційного суспільства стало прийняття Постанови Верховної Ради України «Про Рекомендації парламентських слухань 3 питань розвитку інформаційного суспільства в Україні у 2005 р.», де було встановлено, що стан розбудови інформаційного суспільства в Україні $\epsilon$ недостатнім порівняно зі світовими тенденціями. Основними причинами такої ситуації відповідно до Закону станом на 2005 р. в Україні були:

1) відсутність національної стратегії розвитку інформаційного суспільства в Україні та план дій щодо ії реалізації;

2) недостатній розвиток інформаційної нормативноправової бази;

3) повільне створення національної інформаційної інфраструктури для надання органами державної влади й органами місцевого самоврядування юридичним і фізичним особам інформаційних послуг із використанням Інтернету;

4) відсутність координації зусиль державного і приватного секторів для ефективного використання наявних ресурсів;

5) низький рівень інформаційної представленості України в Інтернет-просторі;

6) недостатня присутність в Інтернеті україномовних інформаційних ресурсів;

7) нерівномірність забезпечення можливості доступу населення до комп'ютерних i телекомунікаційних засобів, поглиблення «інформаційної нерівності» між окремими регіонами, галузями економіки та різними верствами населення [15].

Відповідно, для усунення причин вкрай низького рівня розвитку інформаційного суспільства в Україні тоді були запропоновані такі основні напрями подолання проблеми: прискорене впровадження інформаційно-комунікаційних технологій в усі сфери суспільного життя, у діяльність органів державної влади й органів місцевого самоврядування; державна 
Права людини в Україні та у зарубіжних країнах: традиції та новації

підтримка економічного зростання нових «електронних» секторів економіки (торгівлі, надання комунальних і банківських послуг тощо), вирішення нормативно-правових питань щодо електронної взаємодії; захист інформаційних прав громадян, насамперед щодо доступності інформації, захисту інформації про особу, підтримку демократичних інститутів, удосконалення правового урегулювання питань інтелектуальної власності та мінімізації ризику інформаційної нерівності тощо.

У 2007 р. законодавчо закріплені основні засади розвитку інформаційного суспільства в Україні на 2007-2015 рр., що стало результатом інтеграції України до глобальних міжнародних систем та інфраструктури внаслідок прийняття міжнародних актів, досліджуваних вище.

Законом України «Про Основні засади розвитку інформаційного суспільства в Україні на 2007-2015 рр.» встановлено, що розвиток інформаційного суспільства в Україні та впровадження новітніх ІКТ в усі сфери суспільного життя і в діяльність органів державної влади й органів місцевого самоврядування визначається одним із пріоритетних напрямів державної політики Основними стратегічними цілями розвитку інформаційного суспільства в Україні були визначені:

- захист інформаційних прав громадян, насамперед щодо доступності інформації, захисту інформації про особу, підтримки демократичних інститутів і мінімізації ризику «інформаційної нерівності»;

- прискорення розробки та впровадження новітніх конкурентоспроможних ІКТ в усі сфери суспільного життя, зокрема в економіку України й у діяльність органів державної влади й органів місцевого самоврядування;

- державна підтримка нових «електронних» секторів економіки (торгівлі, надання фінансових і банківських послуг тощо);

- створення загальнодержавних інформаційних систем, насамперед у сферах охорони здоров'я, освіти, науки, культури, охорони довкілля;

- використання ІКТ для вдосконалення державного управління, відносин між державою і громадянами, становлення електронних форм взаємодії між органами державної влади й органами місцевого самоврядування і фізичними та юридичними особами; 
- досягнення ефективної участі всіх регіонів у процесах становлення інформаційного суспільства шляхом децентралізації та підтримки регіональних і місцевих ініціатив [16].

Повертаючись до нормативно-правових актів, котрі регулюють порядок доступу до інформації, варто сказати, що іншими вітчизняними законодавчими актами, що регламентують доступ до інформації та ії використання, $є$ Закон України «Про звернення громадян» і Закон України «Про доступ до публічної інформації», які також містять норми, що передбачають реалізацію права на інформацію за допомогою інформаційно-комунікаційних технологій. Зокрема, ст. 5 Закону України «Про звернення громадян» визначає, що письмове звернення надсилається поштою або передається громадянином до відповідного органу, установи особисто чи через уповноважену ним особу, також може бути надіслане 3 використанням мережі Інтернет, засобів електронного зв'язку (електронне звернення).

У зазначений закон у 2015 р. були внесені зміни, після чого він визначив можливість подання електронних петицій в Україні у ст. 23-1: громадяни можуть звернутися до Президента України, Верховної Ради України, Кабінету Міністрів України, органу місцевого самоврядування 3 електронними петиціями через офіційний веб-сайт органу, якому вона адресована, або веб-сайт громадського об'єднання, яке здійснює збір підписів на підтримку електронної петиції [17].

Законом передбачена процедура подання електронних петицій, вимоги, порядок їх прийняття, розгляду тощо. Петиції, адресовані Президенту України, розглядаються відповідно до Указу Президента України № 523/2015 «Про Порядок розгляду електронної петиції, адресованої Президентові України».

Положення ст. 5 Закону України «Про доступ до публічної інформації» також вказують на електронні механізми здійснення права на інформацію. Зокрема, серед шляхів забезпечення доступу до інформації, які визначаються вказаною статтею, законодавець виділяє систематичне й оперативне оприлюднення інформації на офіційних веб-сайтах у мережі Інтернет і на єдиному державному веб-порталі відкритих даних [18].

Як і Закон України «Про звернення громадян», у 2015 р. Закон України «Про доступ до публічної інформації» також зазнав певних змін у контексті поширення тенденції до цифровізації 
суспільства, а саме - доповнений ст. 10-1: «Публічна інформація у формі відкритих даних». Відповідно законодавець встановив, що публічна інформація у формі відкритих даних - це публічна інформація у форматі, який дозволяє ï автоматизоване оброблення електронними засобами, вільний і безоплатний доступ до неї, а також її подальше використання [18].

Передумовою прийняття таких змін стало прийняття у 2014 р. Постанови Верховної Ради України «Про проведення парламентських слухань на тему: “Законодавче забезпечення розвитку інформаційного суспільства в Україні"», результатом яких стало схвалення Рекомендацій парламентських слухань на тему: «Законодавче забезпечення розвитку інформаційного суспільства в Україні». Це було своєрідним поштовхом для внесення змін до вже чинних і прийняття деяких нових нормативно-правових актів, що регламентують порядок реалізації права на інформацію, у контексті розвитку інформаційного суспільства та цифровізації. У Рекомендаціях вказувалось, що у контексті євроінтеграції України актуалізується проблема вивчення досвіду становлення інформаційного суспільства у країнах-членах Європейського Союзу, а також імплементації норм правових актів ЄС в інформаційне законодавство України. Наголошувалося на тому, що у переліку пріоритетів стратегічного розвитку України особливе місце повинні займати захист прав, свобод і безпеки громадян в інформаційній сфері, відмова від ідей тотального інформаційного контролю та розвиток інноваційних галузей економіки, зокрема вітчизняної індустрії інформаційних технологій, надання послуг і виробництво програмної продукції [19].

Цифровізація торкнулася усіх без винятку сфер суспільного життя, тому відповідні нормативно-правові акти приймаються на різних рівнях і регулюють різні за своїм змістом суспільні відносини. Наприклад, Розпорядження Кабінету Міністрів України «Про схвалення Концепції розвитку цифрової економіки та суспільства України на 2018-2020 рр.» від 17 січня 2018 р. № 67-p. Цей акт надає визначення цифровізації як насичення фізичного світу електронно-цифровими пристроями, засобами, системами та налагодження електронно-комунікаційного обміну між ними, що фактично уможливлює інтегральну взаємодію віртуального та фізичного, тобто створює кіберфізичний простір. Вона передбачає здійснення заходів щодо впровадження відповідних стимулів для цифровізації економіки, суспільної та 
Права людини в Україні та у зарубіжних країнах: традиції та новації

соціальної сфер, усвідомлення наявних викликів та інструментів розвитку цифрових інфраструктур, набуття громадянами цифрових компетенцій, а також визначає критичні сфери та проекти цифровізації, стимулювання внутрішнього ринку виробництва, використання та споживання цифрових технологій. Зазначається, що основна мета цифровізації полягає у досягненні цифрової трансформації наявних і створенні нових галузей економіки, а також трансформації сфер життєдіяльності у нові, більш ефективні та сучасні. Такий приріст $є$ можливим лише тоді, коли ідеї, дії, ініціативи та програми, які стосуються цифровізації, будуть інтегровані, зокрема, в національні, регіональні, галузеві стратегії та програми розвитку [20].

Варто приділити увагу Розпорядженню Кабінету Міністрів України «Про схвалення Стратегії розвитку інформаційного суспільства в Україні» від 15 травня 2013 р. № 386-р. Вона визначила мету, базові принципи, стратегічні цілі розвитку інформаційного суспільства в Україні, завдання, спрямовані на їх досягнення, а також основні напрями, етапи та механізм реалізації iї 3 урахуванням сучасних тоді тенденцій та особливостей розвитку України в перспективі до 2020 р. [21].

Прийняття та реалізація Стратегії - це виконання міжнародних зобов'язань України за результатами роботи Всесвітніх самітів, розглянутих вище, з питань інформаційного суспільства. Це стало своєрідним кроком до отримання Україною можливості стати рівноправним членом глобального інформаційного суспільства.

Значний вклад Стратегії зумовлюється тим, що в ній вперше на загальнодержавному рівні відбулося закріплення термінів, які мають особливе значення для правового регулювання відносин, пов'язаних із реалізацією прав людини у епоху діджиталізації. Йдеться про електронну демократію, електронну економіку, електронну комерцію тощо.

\section{3. Наслідки діджиталізації у сфері реалізації прав людини}

Як зазначалося вище, глобалізація та наслідки інформаційних технологій породжують появу нових та еволюцію вже наявних прав людини, переводячи їх у «цифрову площину». Таким чином, дедалі частіше науковці говорять про існування «цифрових прав», які кидають виклик традиційному розумінню прав 
Права людини в Україні та у зарубіжних країнах: традиції та новації

людини та цим самим трансформують його у правовому, політичному й історичному колі.

Нині науковці та практики досліджують національні та міжнародні демократичні дилеми, спричинені економічними й екологічними кризами, медіа-культурою, збором даних, наглядом і безпекою, що невпинно виникають і тим самим змінюють процес реалізації прав людини

Належно побудована державна політика й ефективне впровадження нових правових засобів, що відповідають сучасності, можуть пом'якшити виклики, які виникають унаслідок створення нових технологій і глобалізації.

Права людини завдяки появі можливостей технологічного, електронного їх застосування у сучасному глобалізованому світі можуть значно покращити якість багатьох важливих для держави процесів.

Національні нормативно-правові акти, про які згадувалося вище, встановили нові способи здійснення деяких прав людини. Насамперед ідеться про реалізацію демократії, тобто влади народу, котра найяскравіше проявляється у таких основоположних правах людини, як право обирати та бути обраним, направляти індивідуальні та колективні звернення до органів державної влади та місцевого самоврядування, брати участь в управлінні державними справами.

Одним із найважливіших викликів глобалізації, визначеним як у наукових колах, так і у політичній сфері, є демократичний дефіцит - недостатній рівень демократії в політичних інституціях і процедурах порівняно з його теоретичним ідеалом. Здебільшого проблему дефіциту демократії відносять до міжнародного права, особливо до діяльності Європейського Союзу, але він насправді $є$ в кожній країні. Основне питання в тому, яке сприйняття демократії в конкретній державі. Чинники, що викликають дефіцит демократії, можна розділити на дві групи: зовнішні та внутрішні. До першої можна віднести міжнародний тероризм, а до другої - політичну байдужість i апатію, недовіру до державної влади, бюрократію, кризу моральних цінностей, використання досягнень науковотехнічного прогресу на шкоду людині

Найціннішим демократичним інструментом $є$ впровадження такої моделі відносин держава - суспільство, що ставить громадян у центр як найважливіших суб'єктів демократії участі. 
Права людини в Україні та у зарубіжних країнах: традиції та новації

Це сприяє протистоянню демократичному дефіциту і, отже, веде до належного рівня управління державою загалом.

Сьогодні одним із способів залучення більшої кількості громадян до демократичних процесів $\epsilon$ електронна демократія. Варто сказати, що використання електронних ресурсів для різних аспектів демократії не лише стає допоміжним ресурсом, a i набуває ознак певної необхідності. Неодноразово у наукових колах підкреслювалися взаємодія та взаємовплив електронного урядування й електронної демократії, зокрема вплив електронного уряду на демократичний процес. Електронна демократія також концептуально пов'язана 3 електронним урядом, але водночас потрібно розуміти, що це не тотожні поняття, і слід відрізняти ці категорії одну від одної [22].

Сучасні тенденції свідчать, що традиційні зв'язки між громадянами та представниками політичних сил слабшають. Водночас відносини між обраними представниками, громадянами, громадянським суспільством і політичною владою розвиваються, тож значно поширюються електронні інструменти, включаючи Інтернет, веб-сайти, соціальні мережі. Вони можуть допомогти мобілізувати виборців, збільшити участь громадян у різних способах покращення надання державних послуг, сприяння інноваціям та економічному зростанню, зрештою навіть зміцнити демократію.

Сьогодні найяскравішим прикладом успішного існування електронної демократії $\epsilon$ Естонія. Країна почала свій шлях до «цифрового суспільства» ще понад 20 років тому, у 1997 р. була започаткована система електронного урядування, за допомогою якої здійснювалося надання державних послуг через мережу Інтернет. Із часом можливості користування Інтернетом значно розширилися, а, відповідно, збільшився і спектр надання держаних послуг за допомогою інформаційних комп'ютерних технологій. Естонія на законодавчому рівні запровадила можливість існування електронних податків, електронну охорону здоров'я й електронне голосування. У 2007 р. Естонія стала першою у світовій практиці країною, що забезпечила своїм громадянам можливість реалізувати їхнє виборче право шляхом голосування через Інтернет на парламентських виборах. У 2017 р. журнал Wired назвав країну «найдосконалішим цифровим суспільством у світі». Поряд з Естонією електронне 
Права людини в Україні та у зарубіжних країнах: традиції та новації

голосування стрімко розвивається й у Великій Британії, Швейцарії та Франції.

Незважаючи на досить довгу історію виникнення різноманітних концепцій та ідей електронної демократії, у сучасному науковому просторі не існує загальноприйнятої узгодженої позиції щодо визначення цього терміна. Серед численних концепцій можна виділити визначення, що мають ознаки як нормативного характеру, так і наукового. I кожне з них так чи інакше акцентує увагу на певній особливості електронної демократії.

Загалом електронна демократія (е-демократія) - це використання інформаційних i комунікаційних технологій для посилення, а в деяких випадках і для заміни представницької демократії.

Науковці, об'єктом досліджень яких стала електронна демократія, мають різні думки щодо цього явища, але більшість із них поділяють єдине переконання, що у сучасних ліберальнодемократичних державах дефіцит часу, ухилення громади від участі у важливих загальнодержавних процесах і відсутність можливостей для обговорення політики можуть бути подолані за допомогою нових форм Інтернет-комунікацій.

Н.В. Грицяк і С.Г. Соловйов, автори навчального посібника «Електронна демократія», розглядають цей термін у широкому та вузькому значеннях. У першому випадку науковці розуміють електронну демократію як застосування ІКТ для забезпечення (електронного супроводу) прав громадян. Широке розуміння електронної демократії передбачає залучення громади за допомогою сучасних інформаційних технологій до вирішення різноманітних суспільно-політичних завдань [23]. Вузьке розуміння охоплює більше технологічну сторону, за допомогою якої громадяни можуть подати різні заяви, звернення, запити до органів влади задля отримання певної довідки чи інформації. Такі дії здійснюються громадянами у межах реалізації їхніх прав, зокрема, права на направлення індивідуальних або колективних звернень, визначеного ст. 40 Конституції України: усі мають право направляти індивідуальні чи колективні письмові звернення або особисто звертатися до органів державної влади, органів місцевого самоврядування та посадових і службових осіб цих органів, що зобов'язані розглянути звернення та дати обгрунтовану відповідь у встановлений законом строк [13]. Тобто фактично це заміна письмової форми здійснення певних 
дій на електронну. Як приклад електронної демократії у широкому розумінні автори наводять інтерактивну участь жителів у засіданні місцевої ради, коли засідання місцевої ради транслюється в Інтернеті в режимі он-лайн, і під час цього кожний, хто виявляє відповідне бажання, може висловити своє ставлення до рішень ради, виступів депутатів і вплинути на позицію органу влади.

Зарубіжні науковці В. Дрожжинов та А. Штрик е-демократію розглядають як використання ІКТ та інформаційної інфраструктури для розвитку й посилення демократичних інститутів i розширення участі громадян у суспільній і політичній діяльності [24].

Схоже визначення пропонує О.А. Баранов: електронна демократія - це демократія, для якої значно підвищується ефективність демократичних інститутів, демократичних процесів i поширення демократичних цінностей за умови застосування різноманітних інструментів, що базуються на максимальному використанні інформаційних комп'ютерних технологій [25].

На думку В.К. Лур'є: «Е-демократія - це інструмент підвищення якості управлінських рішень, що стосуються як кожного окремого учасника політичного процесу, так i суспільства загалом» [26].

Вітчизняне законодавство визначає електронну демократію як форму суспільних відносин, за якої громадяни й організації залучаються до державотворення та державного управління, а також до місцевого самоврядування шляхом широкого застосування IКТ у демократичних процесах. Це дає змогу: посилити участь, ініціативність і залучення громадян на загальнодержавному, регіональному та місцевому рівні до публічного життя; поліпшити прозорість процесу прийняття рішень, а також підзвітність демократичних інститутів; поліпшити зворотну реакцію суб'єктів владних повноважень на звернення громадян; сприяти публічним дискусіям і привертати увагу громадян до процесу прийняття рішень [27]. Таке визначення було встановлене розпорядженням КМУ «Про схвалення Концепції розвитку електронної демократії в Україні та плану заходів щодо її реалізації» у 2017 р. і значно розширило попереднє нормативне визначення 2013 р., яке містилося в іншому розпорядженні КМУ «Про схвалення Стратегії розвитку інформаційного суспільства в Україні». 
Права людини в Україні та у зарубіжних країнах: традиції та новації

3 наведеного вище визначення видно, що визначення електронної демократії, запропоноване законодавцем, спрямоване більше на розширення можливостей для налагодження «змістовного діалогу» між громадянами й органами державної влади, тобто залучення громадськості до використання електронних ресурсів задля реалізації своїх конституційних прав, встановлених ст. 40 Конституції України. У контексті електронної демократії така реалізація можлива через електронні петиції й електронні консультації, але найяскравішим проявом демократії $\epsilon$ саме іï пряма форма вибори. Щодо проведення електронних виборів в Україні поки не має жодних законодавчих передумов. Хоча цифрові технології стають дедалі важливішими у всіх сферах життя, вони ще не відіграють значної ролі у політичних процесах України. Україна ще повинна пройти досить тривалий шлях для забезпечення можливостей проведення електронного голосування, але варто зазначити, що певні кроки назустріч такій меті вже здійснюються. Наприклад, Указом Президента «Про Національну стратегію у сфері прав людини» від 24 березня 2021 р. № 119/2021 одним із основних завдань для забезпечення свободи мирних зібрань та об'єднань, права на участь в управлінні державними справами $\epsilon$ створення умов для запровадження електронної демократії.

Спроби реалізувати електронне голосування на практиці все ж таки були. У парламенті починаючи з 2011 р. були зареєстровані декілька законопроектів, метою яких було вдосконалення системи голосування з урахуванням світового досвіду застосування новітніх електронних і комунікаційних технологій: законопроект № 8656 «Про концепцію запровадження системи електронного голосування», № 10129 «Про внесення змін до деяких законів України щодо забезпечення виборчих прав громадян України шляхом запровадження на виборах голосування поштою та інтернет-голосування», проте усі вони були відкликані або зняті 3 розгляду.

Однією з основних цілей електронної демократії є посилена інтеграція громадян у політичну сферу держави. Підключення до Інтернету дає змогу більшій кількості людей брати участь у багатьох дискусіях, які раніше були недоступні для громадськості. Цифровізація демократії участі спрямована на підвищення прозорості та легітимності політичних систем шляхом демократичного залучення. Зміст електронної 
Права людини в Україні та у зарубіжних країнах: традиції та новації

демократії полягає у сприянні просуванню демократії за допомогою цифрових засобів, забезпеченні прозорості політичних процесів. Це своєрідний засіб сприяння ефективній взаємодії політики, уряду та процесу прийняття рішень.

До засобів прямої демократії відносять подання громадянами звернень до органів державної влади, а однією із його форм $€$ петиція. Така форма взаємодії суспільства із владою стала особливо популярною, і подача електронних петицій приносить користь обом сторонам. Для суспільства це можливість продемонструвати рівень своєї задоволеності владою, проінформувати останню щодо наявних проблем, вплинути на процес прийняття управлінських рішень. Для влади електронні петиції можуть виступати як засіб комунікації із суспільством, своєрідний інструмент зворотного зв'язку із громадськістю.

Починаючи 32000 р. низка парламентів та урядів іноземних держав почали запроваджувати електронні системи подання петицій (електронні петиції). Порівняно 3 більшістю інших способів електронної участі громадян електронні петиції вийшли за межі експериментальної стадії та характеризуються високим рівнем інституціоналізації та процесуальної «зрілості». Отже, сфера дослідження електронних петицій $\epsilon$ особливо перспективною для кращого розуміння відносин між державними установами й е-участю громадян.

Як зазначалося у попередньому підрозділі, поняття «електронна петиція», порядок її подання, строки розгляду та інші, важливі для процесу реалізації права на неї, є законодавчо встановленими, а саме Законом України «Про звернення громадян», Указом Президента України Про Порядок розгляду електронної петиції, адресованої Президентові України, Постановою Кабінету Міністрів України Про затвердження Порядку розгляду електронної петиції, адресованої Кабінету Міністрів України. Порядок розгляду електронної петиції, адресованої органу місцевого самоврядування, визначається відповідною місцевою радою.

Відповідно до Закону України «Про звернення громадян» електронна петиція $\epsilon$ особливою формою колективного звернення громадян до Президента України, Верховної Ради України, Кабінету Міністрів України, органу місцевого самоврядування, яка подається та розглядається в порядку, передбаченому законом [17]. 
Електронну петицію можна розглядати як форму політичної участі громадян, що здійснюється за допомогою інформаційнокомунікаційних систем, метою якої $є$ привернення уваги органів державної влади до питань, котрі становлять суспільний інтерес.

Електронні петиції - це доступний і прозорий інструмент, що дозволяє громадськості ініціювати проблемні питання, відкриває можливості залучити широке коло громадян до вирішення проблеми та передбачає оперативний розгляд питання [28].

Варто сказати, що у правовій доктрині нині існує невелика кількість досліджень, присвячених науково-теоретичному аналізу електронних петицій в Україні. Більшість вчених, розглядаючи це питання, зосереджують увагу на дослідженні процесу, що включає порядок подання петицій, їх підтримку та прийняття.

Порядок подання та розгляду електронних петицій - це процес, який можна розділити на декілька стадій.

Перша - це подання е-петиції, ії реєстрація. Вона здійснюється ініціатором (автором), шляхом розміщення на веб-сайті відповідного органу або громадського об'єднання, що здійснює збір підписів.

Друга стадія - прийняття петиції відповідним органом. Вона включає процес перевірки е-петиції встановленим вимогам. У разі невідповідності електронної петиції оприлюднення такої петиції не здійснюється, про що повідомляється автору (ініціатору) не пізніше строку, встановленого для оприлюднення.

Третя стадія - оприлюднення електронної петиції на офіційному веб-сайті відповідного органу. Дата оприлюднення $\epsilon$ датою початку збору підписів на її підтримку.

Четверта стадія - збір підписів. За загальним правилом, електронна петиція повинна набрати 25000 підписів громадян протягом не більше трьох місяців із дня оприлюднення петиції.

П’ята стадія - розгляд е-петиції відповідним органом. Він відбувається не пізніш як через три робочі дні після набрання необхідної кількості підписів на підтримку петиції, а в разі отримання електронної петиції від громадського об'єднання - не пізніш як через два робочі дні після отримання такої петиції. Розгляд електронної петиції здійснюється невідкладно, але не пізніше десяти робочих днів із дня оприлюднення інформації про початок її розгляду [17]. 
Шоста стадія - публічне оголошення про підтримку або непідтримку електронної петиції. Це здійснюється на офіційному веб-сайті відповідного органу державної влади.

У науково-правовій доктрині зустрічаються думки щодо доцільності існування ще однієї стадії - надсилання петиції адресату. Цей етап зустрічається лише у випадках, коли збір підписів на підтримку петиції здійснюється через сайт громадського об'єднання. Якщо відповідна петиція набрала необхідну кількість підписів, то не пізніше наступного дня після завершення строку збирання підписів вона має бути надіслана громадським об'єднанням на офіційний веб-сайт органу влади, якому адресована [29].

Важливим і дискусійним залишається питання анонімності в електронних петиціях. Анонімні петиції не приймаються до розгляду, оскільки в електронній петиції має бути викладено суть звернення, зазначено прізвище, ім'я, по батькові автора (ініціатора) електронної петиції, адресу електронної пошти. Крім того, список осіб, котрі проголосували, також залишається відкритим - на веб-сайті відповідного органу або громадського об'єднання, що здійснює збір підписів, обов'язково зазначаються дата початку збору підписів та інформація щодо загальної кількості та переліку осіб, які підписали петицію [30].

Така ситуація ілюструє деяку неоднозначність питання анонімності у демократії за участі громадян. Аналіз Закону України «Про звернення громадян» дає підстави зробити висновок щодо прозорості голосування на підтримку електронної петиції, тоді як Виборчий Кодекс України встановлює, що наші політичні уподобання захищаються таємним голосуванням. Таким чином, у випадку електронних петицій спосіб голосування не дозволяє громадянам вільно висловлювати свою думку, адже вони можуть боятися нападів із боку тих, хто не підтримує ту чи іншу петицію. Тобто підписи за петицію залишаються під прицілом громадськості.

Сьогоднішні емпіричні дослідження показують, що електронна петиція добре сприймається загалом і навіть може залучити молодь, однак і досі гостро стоїть проблема у подоланні розбіжності у політичній участі (включаючи «цифровий розрив») на основі соціально-демографічних характеристик. Ця проблема може бути вирішена за допомогою впровадження цифрової інклюзії (електронної інклюзії) - втіленого у практиці на законодавчому рівні підходу, який би відповідав потребам 
Права людини в Україні та у зарубіжних країнах: традиції та новації

окремих людей і громад загалом. Тобто такого підходу, який би охоплював не тільки доступ до Інтернету, але також і наявність апаратного забезпечення, програмного забезпечення, навчання навичок цифрової грамотності, необхідних для ефективного використання інформаційних і комунікаційних технологій.

Ще однією проблемою електронних петицій $\epsilon$ те, що публікується практично кожний запит, через що виникають несерйозні чи жартівливі петиції. Слід розглянути можливість впровадження суворіших критеріїв прийнятності відповідно до міжнародних практик і перевіряти перед публікацією запиту, чи відповідає він суспільному інтересу [29].

\section{Висновки}

Відкритим залишається питання правового регулювання переходу у цифровий формат і використання цифрового формату у правовідносинах між усіма суб'єктами. Поняття «цифрові права» або «цифрові правовідносини» поки не відображені у законодавстві. Варто погодитися 3 тим, що прийняті новели законодавства $\epsilon$ першим важливим кроком до необхідних перетворень. Так, вони не можуть повною мірою забезпечити необхідний рівень правового регулювання наявних правовідносин, але служать своєрідним фундаментом для формування правовідносин і основою для майбутніх перетворень у цифровій сфері.

Особлива увага повинна бути приділена аналізу й оцінці європейського законодавства, спрямованого на гармонізацію національного законодавства щодо впровадження телекомунікаційних можливостей, і їхнього впливу на захист прав людини. Ще у 2006 р. Європейський Союз запровадив Директиву ЄC про збереження даних. Ця Директива вимагає зберігання даних комунікацій кожного європейського громадянина до двох років із метою розслідування, виявлення та переслідування тяжких злочинів. Директива спричинила значне занепокоєння серед законодавців, органів захисту даних i приватного сектору.

Нині основними та найбільш результативними наслідками діджиталізації у сфері прав і свобод людини та громадянина стали електронне урядування й електронна демократія. Електронне урядування включає взаємозв'язок двох важливих аспектів. Так, 3 одного боку, це зусилля для досягнення соціальної інтеграції, а з іншого - це поняття електронного уряду 
Права людини в Україні та у зарубіжних країнах: традиції та новації

як сучасної сторони IКТ. Електронне урядування може усунути соціальне відчуження та сприяти соціальній участі. Основним завданням для ефективного функціонування електронного урядування $є$ синтез цих двох аспектів.

Участь громадськості вважається засобом демократизації політичних процесів. У міру зростання технічного прогресу дедалі більше довіри надається ІКТ як інструментам демократизації політичних процесів шляхом посилення та сприяння участі громадян у них. Яскравим прикладом тут виступає електронна демократія, однак варто підкреслити, що технології, як і будь-які інші інструменти демократії не $\epsilon$ неупередженими, тому остання повинна включати міркування щодо соціального імпорту, оскільки, як і у випадку 3 електронним урядуванням, відсоток залучення громадян $\epsilon$ низьким порівняно 3 кількістю населення загалом. Поява цифрового розриву $\epsilon$ доказом того, що, якщо не будуть застосовуватися необхідні засоби для зменшення такого розриву, це може призвести до ще більшого негативного впливу на вже наявну соціальну ізоляцію. Соціальна інтеграція повинна існувати не лише як стратегія протидії соціальній ізоляції загалом, але також і як протидія цифровому розриву, який заважає громадянам брати участь у політичних процесах, тому важливим чинником успішного функціонування електронної демократії $\epsilon$ соціальна інтеграція. Вона не лише виконує основоположну роль як передумова участі громадськості за допомогою ІКТ, а й виступає своєрідним вирішенням проблеми боротьби із соціальною ізоляцією за допомогою відповідних регуляторних механізмів.

Електронні петиції як одна із форм електронної демократії $€$ досить популярними у всьому світі загалом і в Україні зокрема. Сьогоднішні емпіричні дослідження показують, що електронні петиції схвально сприймаються населенням і часто використовуються, але $\epsilon$ низка певних особливостей, що заважають електронним петиціям бути однією із провідних форм висловлення думки громадськості. По-перше, результат громадських ініціатив не завжди залежить від думки тих людей, хто проголосував за неї. Чим більш важливою і актуальною $\epsilon$ представлена у петиції проблема, тим складніше домогтися ії рішення за допомогою порталів петицій, особливо це стосується питань вседержавного значення. Більшого значення набуває та якісніший результат демонструє використання електронних 
Права людини в Україні та у зарубіжних країнах: традиції та новації

петицій на місцевому рівні. Можна зробити висновок, що онлайнплатформи для петицій поки що лише частково виконують функцію інструменту електронної участі громадян. Їх роль розкривається у залученні уваги громадськості до проблеми та поширенні інформації, а конкретне рішення актуальної суспільної проблеми повністю залежить від державної політики, а отже, від рішення органів державної влади.

Крім того, виникає певна проблема анонімності електронних петицій, оскільки політична участь громадян у мережі Інтернет викликає важливу дискусію щодо балансу між необхідністю прозорості, з одного боку, та правом на анонімність, з іншого.

\section{Список використаних джерел:}

1. Латковська Т.А., Марущак А.В., Олексій У.О. Правові та теоретичні проблеми визначення інтернет-банкінгу в Україні. Фінансово-кредитна діяльність: проблеми теорії $і$ практики. Львів. 2021. № 1 (36). С. 27-34.

2. Karel Vasak. Human Rights: A Thirty-Year Struggle: the Sustained Efforts to give Force of law to the Universal Declaration of Human Rights. UNESCO Courier 30:11, Paris : United Nations Educational, Scientific, and Cultural Organization, November 1977.

3. Ситдикова Р.И., Ситдиков Р.Б. Цифровые права как новый вид имущественных прав. Гражданское право. Вопросы имущественной политики. 2018. № 9. С. 75-80.

4. Володовська В., Дворовий М. Права людини онлайн: Порядок денний для України. Київ : ГО «Лабораторія цифрової безпеки», 2019. 56 с

5. Овчинников А.И., Фатхи В.И. Цифровые права как объекты гражданских прав. Философия права. 2019. № 3 (90). C. 104-112.

6. Барабаш 0.0. Четверте покоління прав людини: загальнотеоретична характеристика. Вісник Національного університету «Львівська політехніка». Серія : Юридичні науки. 2016. № 837. С. 213-217.

7. Попович Т., Шаварин А. Сутнісне наповнення четвертого покоління прав людини. Підприємнищтво, господарство і право. 2019. № 12. С. 266-271.

8. Souter, D. Whose Summit? Whose Information Society? Developing Countries and Civil Society at the World Summit on the Information Society. Melville, South Africa : Association for Progressive Communications, 2007. 
Права людини в Україні та у зарубіжних країнах: традиції та новації

9. Загальна декларація прав людини від 10 рудня 1948 р. офіційний вісник України. 2008. № 93. Т. 3103.

10. Декларація принципів «Побудова інформаційного суспільства - глобальне завдання у новому тисячолітті» від 12 грудня 2003 p. URL: https://zakon.rada.gov.ua/laws/show/ 995_c57\#Text (дата звернення: 11.05.2021).

11. Туніська програма для інформаційного суспільства від 18 листопада 2005 p. URL: http://informationsociety.wordpress.com/ basics/wsis_outcomes/tp/ (дата звернення: 11.05.2021).

12. Резолюция Совета ООН по правам человека A/HRC/RES/20/8 «Поощрение, защита и осуществление прав человека в Интернете» от 16 червня 2012 p. URL: https://undocs.org/ru/A/HRC/RES/20/8 (дата звернення: 11.05.2021).

13. Конституція України від 28 червня 1996 р. № 254к/96-ВР. URL: $\quad$ https://zakon.rada.gov.ua/laws/show/254\%D0\%BA/96D0\%B2\%D1\%80\#n4690 (дата звернення: 28.04.2021).

14. Про інформацію : Закон України від 02 жовтня 1992 р. № 2657-XII. Відомості Верховної Ради Украӥни. 1992. № 48. Ст. 650.

15. Про Рекомендації парламентських слухань 3 питань розвитку інформаційного суспільства в Україні : Постанова Верховної Ради України від 01 грудня 2005 р. №3175-IV. Відомості Верховної Ради України. 2006. № 15. Ст. 131.

16. Про Основні засади розвитку інформаційного суспільства в Україні на 2007-2015 рр. : Закон України від 09 січня 2007 р. № 537-V. Відомості Верховної Ради України. 2007. № 12. Ст. 102.

17. Про звернення громадян : Закон України від 02 жовтня 1996 р. № 393/96-ВР. Відомості Верховної Ради Украӥни. 1996. № 47. Ст. 256.

18. Про доступ до публічної інформації : Закон України від 13 січня 2011 р. № 2939-VI. Відомості Верховної Ради України. 2011. № 32. Ст. 314.

19. Про Рекомендації парламентських слухань на тему: «Законодавче забезпечення розвитку інформаційного суспільства в Україні» : Постанова Верховної Ради України від 03 липня 2014 р. № 1565-VII. Відомості Верховної Ради. 2014. № 33. Ст. 1163.

20. Про схвалення Концепції розвитку цифрової економіки та суспільства України на 2018-2020 роки та затвердження плану заходів щодо її реалізації : Розпорядження Кабінету Міністрів України від 17 січня 2018 р. № 67-p. URL: 
Права людини в Україні та у зарубіжних країнах: традиції та новації

https://zakon.rada.gov.ua/laws/show/67-2018-\%D1\%80\#Text (дата звернення: 28.04.2021).

21. Про схвалення Стратегії розвитку інформаційного суспільства в Україні : Розпорядження Кабінету Міністрів України від 15 травня 2013 р. № 386-p. URL: https://zakon.rada.gov.ua/laws/show/386-2013-\%D1\%80\#Text (дата звернення: 01.05.2021).

22. Гнатовська A.I., Марущак А.В. Концептуальні засади електронної демократії та електронного урядування в Україні. Evropský politický a právní diskurz. 2021. V. 8. № 2. C. 63-68.

23. Грицяк Н.В., Соловйов С.Г. Електронна демократія : навчальний посібник. 2015. Київ : НАДУ. 66 с.

24. Дрожжинов В.И., Штрик А.А. Электронная демократия и поддерживающие ее технологии. Технологии информационного общества. Интернет и современное общество : тр. VI Всеросс. объединенной конференции (3-6 ноября 2003, г. СанктПетербург). С. 101-110.

25. Баранов О.А. Правові проблеми «електронної демократії». Інформація і право. 2017. № 1. С. 28-38.

26. Лур'є В.К. Концепція електронної демократії. Вісник Національного університету «Юридична академія України імені Ярослава Мудрого». Серія : Політологія. 2017. № 2. С. 210-216.

27. Про схвалення Концепції розвитку електронної демократії в Україні та плану заходів щодо їі реалізації, 2017 (Кабінет Міністрів України). Обіційний сайт Верховної Ради України. URL: https://zakon.rada.gov.ua/laws/show/797-2017\%D1\%80\#Text (18.02.2021p.)

28. Собків Я.М. Електронна петиція як одне з інформаційних прав людини і громадянина. Право і суспільство. 2015. № 6. С. 61-66.

29. Пасічнюк В.Б., Гонтарук О.С. Електронні петиції в Україні: сучасний стан та правове забезпечення. Молодий вчений. 2019. № 12.1 (76.1). С. 51-54.

30. Колесников О. Е-петиції у системі місцевої демократії: досвід обласних центрів України. Аналітичні матеріали. URL: http://samoorg.com.ua/wpcontent/uploads/2017/02/Petitsiyi_gotov-1.pdf (дата звернення: 04.03.2021). 